\section{DELTA OPIOID EXTENDS HYPOTHERMIC PRESERVATION TIME OF THE LUNG}

To test the hypothesis that a delta opioid, DADLE ([D-Ala ${ }^{2}$, D-Leu $\left.{ }^{5}\right]-e n-$ kephalin), could protect tissue from ischemic damage during hypothermic lung preservation, we studied three groups of rats. In group $1(n=8)$, lung function was studied immediately after harvesting. In group $2(n=8)$, the lung was flushed with $4^{\circ} \mathrm{C}$ Euro-Collins solution and preserved for 24 hours. In group $3(n=8)$, the lung was flushed with $4^{\circ} \mathrm{C}$ Euro-Collins solution plus DADLE (1 mg/kg) and preserved for 24 hours. Lung function was studied by using a living rat perfusion model. Venous blood from the host rat perfused the pulmonary artery of the isolated lung. Blood from the isolated lung was returned to the carotid artery of the host rat with a roller pump. Severe pulmonary edema, hemorrhage, and occlusive pulmonary artery resistance occurred in group 2 within 30 minutes of perfusion. Perfusion studies were carried out for more than 60 minutes in groups 1 and 3. Pulmonary blood flow was lower in group 2 than in either group 1 or group 3. Pulmonary vascular resistance was much higher in group 2 than in groups 1 and $3(p<0.05)$. Airway pressure and airway resistance were much higher in group 2 than in groups 1 and $3(p<0.05)$. Airway resistance was also higher in group 3 than in group 1 after 20 minutes of perfusion $(p<0.05)$. Oxygen tensions from the pulmonary vein of the isolated lung in group 2 were lower than those in groups 1 and $3(p<0.05)$. Alveolararterial oxygen difference was much higher in group 2 than in groups 1 and $3(p<0.05)$. Lung tissue wet/dry weight ratio after perfusion was much higher in group 2 than in groups 1 and 3 . The results clearly show, for the first time, that DADLE can effectively enhance hypothermic lung preservation in rats. (J Thorac Cardovasc Surg 1996;111:259-67)

Guanghan Wu, MD, ${ }^{a}$ Futing Zhang, MD, ${ }^{a}$ Robert K. Salley, MD, ${ }^{a}$

John N. Diana, $\mathrm{PhD},{ }^{\mathrm{b}}$ Tsung-Ping $\mathrm{Su}, \mathrm{PhD},{ }^{c}$ and Sufan Chien, $\mathrm{MD},{ }^{\mathrm{a}}$

Lexington, Ky., and Baltimore, $M d$.
$D^{\prime}$ uring the past 30 years, various methods have been developed for preserving solid organs for transplantation. In many cases, these methods have included flushing or perfusing organs with cold crystalloid solution or plasma. The recent development of the University of Wisconsin solution now permits kidneys to be stored for 72 hours and livers

From the Departments of Surgery and Physiology and Biophysics, ${ }^{\text {b }}$ University of Kentucky Medical Center, Lexington, Ky.; and the National Institute on Drug Abuse, IRP, Baltimore, $\mathrm{Md}^{\mathrm{C}}$

Supported by National Institutes of Health grant Nos. GM-43890 and HL-36552.

Received for publication July 20, 1994.

Accepted for publication April 27, 1995.

Address for reprints: Sufan Chien, MD, Department of Surgery, University of Kentucky Medical Center, 800 Rose St., Lexington, $\mathrm{KY} 40536$.

Copyright (C) 1996 by Mosby-Year Book, Inc.

$0022-5223 / 96 \$ 5.00+0 \quad \mathbf{1 2 / 1 / 6 5 8 9 6}$ for 24 hours in animal studies. However, safe clinical preservation times for the heart and lungs are still limited to 4 to 6 hours, no matter what solution is used (including University of Wisconsin solution, Euro-Collins solution, low-potassium dextran solution, University of California-Los Angeles solution, and the above solutions with many additives). In our normothermic multiple organ preservation studies, we found that a delta opioid, DADLE ([D-Ala ${ }^{2}$, D-Leu ${ }^{5}$-enkephalin), could extend tissue survival time substantially. The principal mechanism by which DADLE extended tissue survival time was thought to be related to its ability to protect tissue from ischemic damage in several aspects. ${ }^{1}$ Because of technical difficulties, normothermic multiple organ preparations are used by only a few groups around the world, ${ }^{2,3}$ and the use of DADLE in such preparations is limited at the present time. To test the hypothesis that DADLE could also protect 
tissue from ischemic damage during hypothermia, we performed an isolated lung preservation study and found that DADLE could substantially enhance hypothermic lung preservation. This article reports the results of that study.

\section{Methods}

Adult Sprague-Dawley rats (250 to $300 \mathrm{gm}$ ) were allowed free access to food and water before operation. All animals received humane care in compliance with the "Principles of Laboratory Animal Care" formulated by the National Society for Medical Research and the "Guide for the Care and Use of Laboratory Animals" prepared by the Institute of Laboratory Animal Resources and published by the National Institutes of Health (NIH Publication No. 86-23, revised 1985).

Preparation of hypothermic isolated lung storage. The rat was anesthetized by intraperitoneal injection of sodium pentobarbital ( 50 to $55 \mathrm{mg} / \mathrm{kg}$ ). The cervical trachea was cannulated, and the animal's lungs were ventilated with room air by means of a rodent respirator. Tidal volume of 2.5 to $3.5 \mathrm{ml}$, rate 40 to $50 \mathrm{rpm}$, and peak end-expiratory pressure of $0.5 \mathrm{~cm} \mathrm{H}_{2} \mathrm{O}$ were maintained. The retrosternal space was exposed by blunt dissection, and two large straight clamps were applied in a parallel fashion across the sternum. Care was taken not to injure the lungs and vessels beneath. The chest was opened through a median sternotomy. After intravenous administration of $1 \mathrm{mg}$ heparin sodium, the inferior pulmonary ligaments were carefully divided. The left superior vena cava was divided and ligated. The hilum of the left lung was approached anteriorly, and the vessels and bronchus were separated by blunt dissection. The left pulmonary artery was dissected, and a suture was placed around it. The main pulmonary artery was transected through the transverse sinus, and a cannula was placed in the left pulmonary artery through the transected main pulmonary artery. The suture around the left pulmonary artery was tied, and the left atrium was partly excised for decompressing. The left lung was flushed with $4^{\circ} \mathrm{C}$ preservation solution until the lung was completely white. The lung was removed and preserved at $4^{\circ} \mathrm{C}$ for 24 hours before functional studies.

Technique of isolated lung function studies. A perfusion apparatus consisting of a living host rat and a temperature-controlled, humidified chamber was used for isolated lung function studies. The host rat was anesthetized by intraperitoneal injection of sodium pentobarbital (50 to $55 \mathrm{mg} / \mathrm{kg}$ ). The cervical trachea was cannulated, and the animal's lungs were ventilated with room air by a rodent respirator. Tidal volume of 2.5 to $3.5 \mathrm{ml}$ and rate of 40 to $50 \mathrm{rpm}$ were maintained. The right internal jugular vein was cannulated with a 2 $\mathrm{mm}$ catheter. Heparin sodium $3 \mathrm{mg} / \mathrm{kg}$ was infused intravenously, and both carotid arteries were cannulated with $1 \mathrm{~mm}$ catheters. The catheter in the right carotid artery was connected to a pressure transducer for arterial blood pressure monitoring. The host rat was placed above the isolated lung in such a way that blood from the host rat was withdrawn by a constant hydrostatic pressure of $20 \mathrm{~mm} \mathrm{Hg}$ from the right internal jugular vein to perfuse the pulmonary artery of the isolated lung. A Transonic flow probe (Transonic Systems, Inc., Ithaca, N.Y.) was incorporated into the perfusion line for flow measurements. The isolated lung was suspended in a perfusion chamber, which was immersed in a $37^{\circ} \mathrm{C}$ water bath. Blood returned from the isolated lung was collected in the perfusion chamber. A roller pump returned the blood from the perfusion chamber to the left carotid artery of the host rat. The rate of blood returning to the host rat was adjusted to maintain satisfactory systemic pressure (Fig. 1). During the perfusion period, the isolated lung was ventilated with room air at respiratory rate of 40 to 50 $\mathrm{rpm}$, tidal volume of $2.5 \mathrm{ml}$, and peak end-expiratory pressure of $0.5 \mathrm{~cm} \mathrm{H}_{2} \mathrm{O}$.

After an initial 5- to 10-minute equilibration period, blood samples from the pulmonary artery and vein were taken simultaneously every 10 minutes for blood gas analysis and alveolar-arterial oxygen difference calculation with the IL BGE Blood Gas and Electrolytes Analyzer (Instrumentation Laboratories, Lexington, Mass.). Perfusion pressure, perfusion flow, airway pressure, and tidal volume were recorded continuously on a Gould multichannel recorder (Gould Inc, Centerville, Ohio). Using these parameters, we calculated pulmonary vascular resistance and airway resistance. At the end of the experiment, lung tissue samples were taken for wet/dry weight ratio measurements.

Animal groups studied. Twenty-four rats were used in this study. The rats were divided into three groups. Group 1 rats $(n=8)$ were used as normal controls. The left lungs were removed and immediately transferred to the perfusion apparatus for function studies. In this group, no interruption of ventilation occurred, and interruption of lung perfusion was routinely less than 10 to 20 seconds. Lung function in this group was assumed to be normal. In group $2(n=8)$, the left lungs were flushed with 10 to 15 $\mathrm{ml}$ of $4^{\circ} \mathrm{C}$ Euro-Collins solution at a gravity gradient of 20 $\mathrm{cm} \mathrm{H}_{2} \mathrm{O}$ and immersed in $4^{\circ} \mathrm{C}$ Euro-Collins solution for 24 hours. In group $3(n=8)$, the left lungs were also flushed with 10 to $15 \mathrm{ml}$ of $4^{\circ} \mathrm{C}$ Euro-Collins solution, followed by $5 \mathrm{ml}$ of $4^{\circ} \mathrm{C}$ saline solution containing DADLE (1 mg/kg, Peninsula Lab, Belmont, Calif.) and then immersed in $4^{\circ} \mathrm{C}$ Euro-Collins and DADLE solution for 24 hours. In groups 2 and 3, the bronchus was clamped at the end of inspiration to keep the lung inflated during storage.

Statistical analysis. Two-way analysis of variance was used for repeated measurements. If significance was established, the Student-Newman-Keuls test was used to analyze the difference between individual groups. A value of $p<0.05$ was considered significant. All results were expressed as means \pm standard error of the mean.

\section{Results}

Severe pulmonary edema and hemorrhage occurred in group 2 (Euro-Collins solution alone) within 30 minutes of perfusion, and no preparation could be perfused for more than 30 minutes because of occlusive pulmonary resistance. This phenome- 


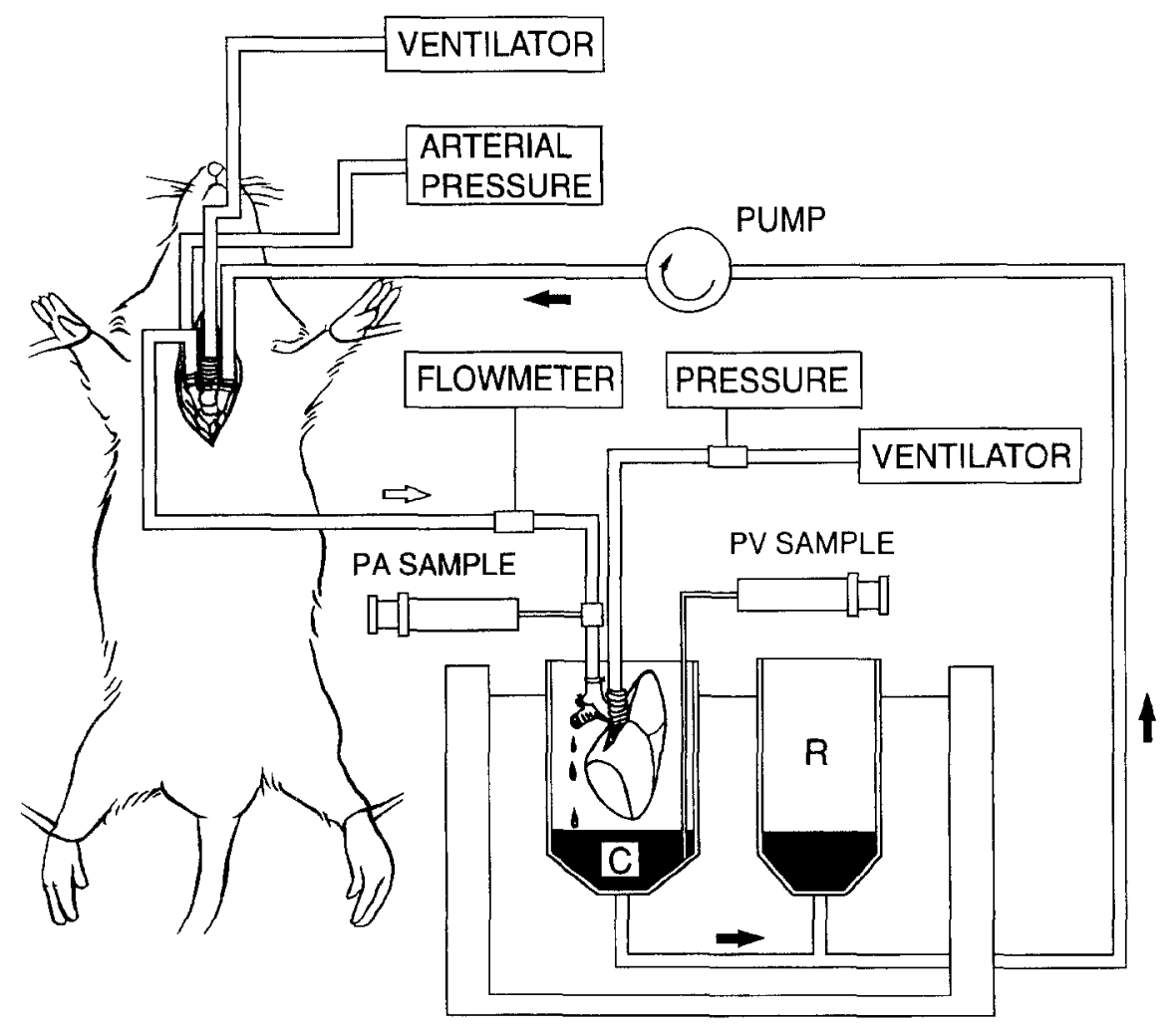

Fig. 1. Apparatus for isolated lung perfusion study. Venous blood from the host rat is used to perfuse the lung. Blood returned from the lung is infused into the carotid artery of the host rat. $P A$, Pulmonary artery; $P V$, pulmonary vein; $C$, perfusion chamber, $R$, reservoir.

non did not occur in either group 1 (control) or group 3 (Euro-Collins plus DADLE), where perfusion studies could be carried out for more than 60 minutes in these two groups. Oxygen tension and carbon dioxide tension in the pulmonary artery and vein of the isolated lung during the 60-minute reperfusion period remained stable and were comparable between groups 1 and 3. Pulmonary vascular resistance and airway resistance were also stable during the perfusion period in these two groups.

Blood flow and pulmonary vascular resistance of the isolated lung. Pulmonary blood flow ranged from $2.06 \pm 0.25$ to $3.50 \pm 0.56 \mathrm{ml} / \mathrm{min}$ in group 1 , from $0.65 \pm 0.10$ to $0.87 \pm 0.10 \mathrm{ml} / \mathrm{min}$ in group 2, and from $1.68 \pm 0.09$ to $1.94 \pm 0.21 \mathrm{ml} / \mathrm{min}$ in group 3. Pulmonary blood flow was lower in group 2 than in either group 1 or group 3 . In group 1 , pulmonary vascular resistance ranged from $7.96 \pm 0.76$ to 14.00 $\pm 2.60 \mathrm{~mm} \mathrm{Hg} / \mathrm{ml} / \mathrm{min}$; in group 2, it ranged from $33.00 \pm 5.00$ to $50.50 \pm 11.00 \mathrm{~mm} \mathrm{Hg} / \mathrm{ml} / \mathrm{min}(p<$ 0.05 as compared with group 1 and 3 ); and in group
3 , it ranged from $13.60 \pm 1.00$ to $15.00 \pm 1.00 \mathrm{~mm}$ $\mathrm{Hg} / \mathrm{ml} / \mathrm{min}$. Because of high pulmonary vascular resistance in group 2, perfusion could not be continued after 30 minutes, indicating severe tissue edema and damage in this group. No difference was found in pulmonary vascular resistance between group 1 and group 3 (Fig. 2).

Airway pressure and resistance of the isolated lung. When tidal volume $2.5 \mathrm{ml}$ was used, airway pressure ranged from $6.4 \pm 0.4$ to $9.3 \pm 1.2 \mathrm{~mm} \mathrm{Hg}$ in group 1, from $13.9 \pm 0.9$ to $17.6 \pm 1.2 \mathrm{~mm} \mathrm{Hg}$ in group 2, and from $9.3 \pm 0.8$ to $13.3 \pm 1.2 \mathrm{~mm} \mathrm{Hg}$ in group 3. Airway pressure was much higher in Group 2 ( $p<0.05$ as compared with group 1 and group 3 ). It was also higher after 20 minutes of perfusion in group 3 than in group $1(p<0.05)$.

Airway resistance ranged from $2.6 \pm 0.2$ to $3.4 \pm$ $0.4 \mathrm{~mm} \mathrm{Hg} / \mathrm{ml}$ in group 1 , from $5.5 \pm 0.3$ to $7.0 \pm 0.4$ $\mathrm{mm} \mathrm{Hg} / \mathrm{ml}$ in group 2, and from $3.8 \pm 0.4$ to $5.0 \pm$ $0.5 \mathrm{~mm} \mathrm{Hg} / \mathrm{ml}$ in group 3. Airway resistance was much higher in group 2 than in groups 1 and 3 ( $p<$ 


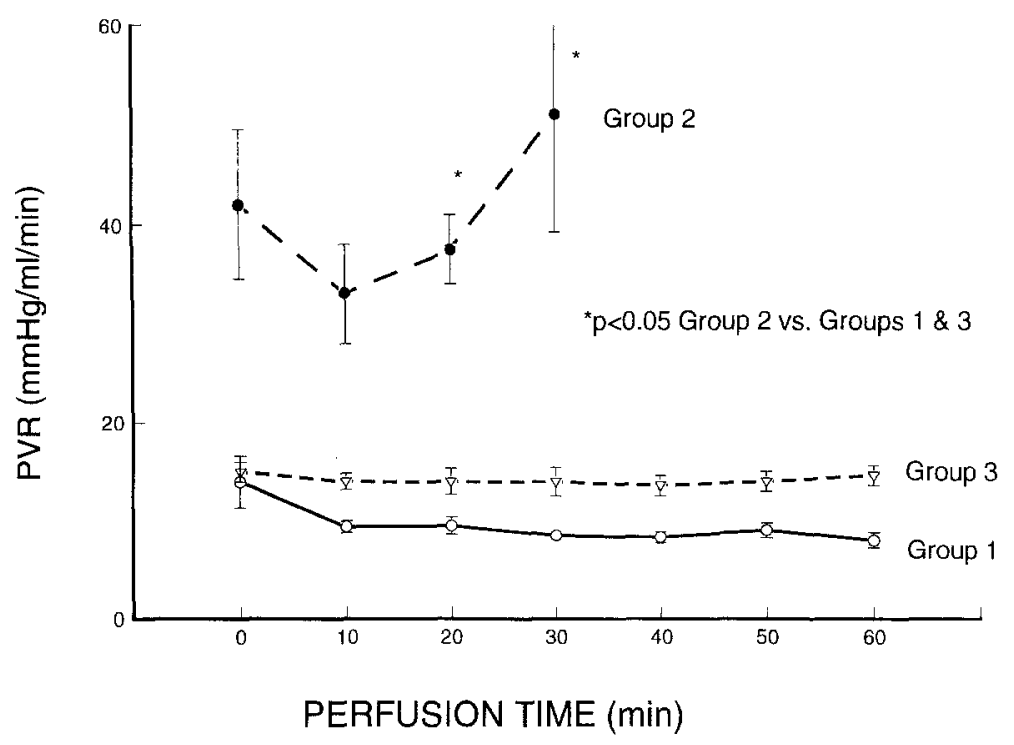

Fig. 2. Comparison of pulmonary vascular resistance $(P V R)$ in the three groups.

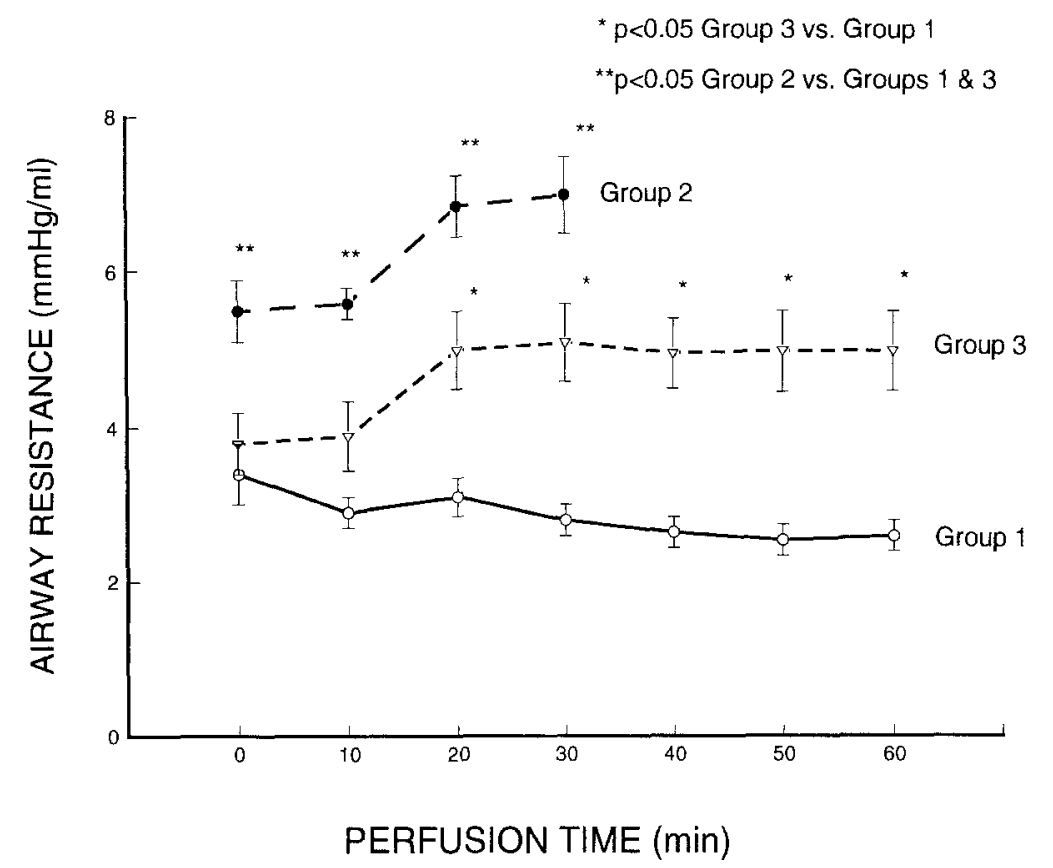

Fig. 3. Comparison of airway resistance in the three groups.

$0.05)$. However, airway resistance was also higher in group 3 than in group 1 after 20 minutes of perfusion $(p<0.05$, Fig. 3).

Blood gases in the inflow and outflow of the isolated lung. Mean oxygen tension in the pulmonary artery (before oxygenation) was $33 \pm 1.6$ to $36 \pm 2.1$ $\mathrm{mm} \mathrm{Hg}$ in group $1,48 \pm 5$ to $52 \pm 7 \mathrm{~mm} \mathrm{Hg}$ in group 2 , and $53 \pm 4.0$ to $60 \pm 3.7 \mathrm{~mm} \mathrm{Hg}$ in group 3. Mean oxygen tensions from the pulmonary vein (after oxygenation by the isolated lung) were $130 \pm 13$ to $180 \pm 11 \mathrm{~mm} \mathrm{Hg}$ in group $1,70 \pm 9.0$ to $92 \pm 14 \mathrm{~mm}$ $\mathrm{Hg}$ in group 2, and $116 \pm 8.0$ to $173 \pm 21 \mathrm{~mm} \mathrm{Hg}$ in group 3. Oxygen tensions in group 2 were lower than in groups 1 and 3 during perfusion and worsened when perfusion time was longer, indicating impaired oxygenation capacity in this group (Fig. 4). 


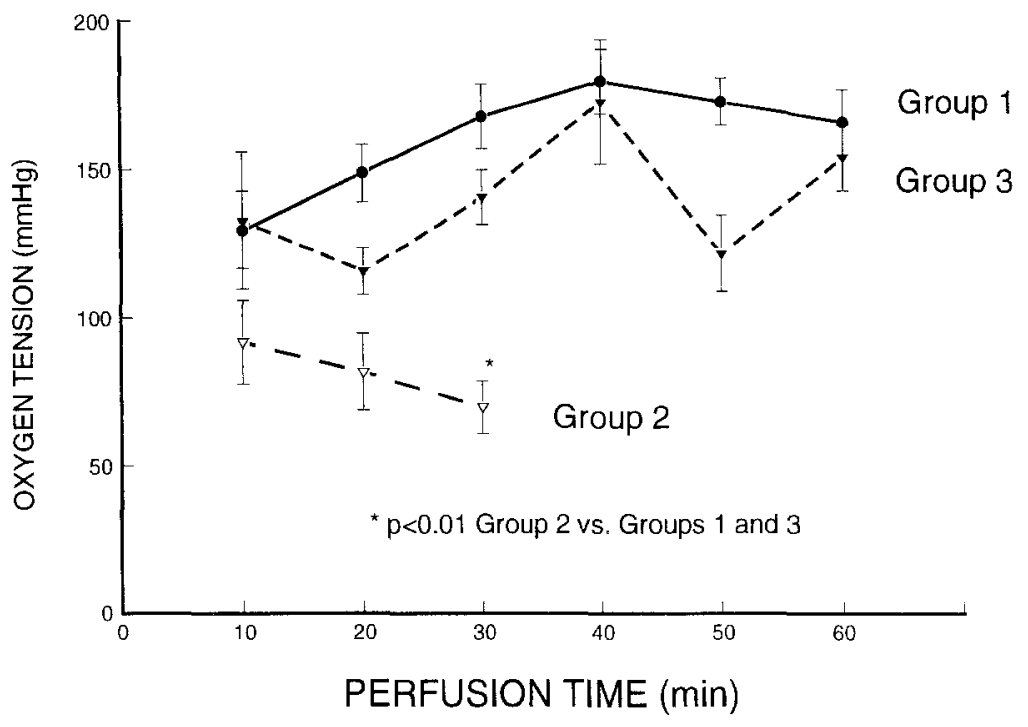

Fig. 4. Comparison of oxygen tensions in the isolated pulmonary vein in the three groups.

Carbon dioxide tension in the pulmonary artery was $30 \pm 2.7$ to $38 \pm 2 \mathrm{~mm} \mathrm{Hg}$ in group $1,41 \pm 4$ to $41 \pm 7 \mathrm{~mm} \mathrm{Hg}$ in group 2 , and $16 \pm 2$ to $23 \pm 3 \mathrm{~mm}$ $\mathrm{Hg}$ in group 3. Carbon dioxide tension in the pulmonary vein was $17 \pm 0.6$ to $19 \pm 2.0 \mathrm{~mm} \mathrm{Hg}$ in group $1,17 \pm 2.5$ to $23 \pm 4 \mathrm{~mm} \mathrm{Hg}$ in group 2, and $16 \pm 2$ to $23 \pm 3 \mathrm{~mm} \mathrm{Hg}$ in group 3. No statistically significant difference was found among the three groups, although perfusion time was much shorter in group 2.

Alveolar-arterial oxygen difference. Alveolar-arterial oxygen difference ranged from $4.68 \pm 4.62$ to $30.29 \pm 10.28 \mathrm{~mm} \mathrm{Hg}$ in group 1 , from $44.01 \pm 10.94$ to $54.88 \pm 6.16 \mathrm{~mm} \mathrm{Hg}$ in group 2, and from $0.46 \pm$ 0.46 to $23.49 \pm 5.45 \mathrm{~mm} \mathrm{Hg}$ in group 3. Alveolararterial oxygen difference was much higher in group 2 than either group 1 or group 3 ( $p<0.05$, Fig. 5).

Lung tissue wet/dry weight ratio after perfusion. Lung tissue wet/dry weight ratio after perfusion was $6.3 \pm 0.4$ in group $1,8.7 \pm 0.5$ in group 2 , and $5.7 \pm$ 0.7 in group 3 . Tissue wet/dry weight ratio was much higher in group 2 than in groups 1 and $3(p=0.005)$, even though the perfusion time was only 30 minutes in group 2. No difference was found in tissue wet/dry ratio between group 1 and group 3 (Fig. 6).

\section{Discussion}

The scarcity of suitable donor organs is the main limitation to transplantation. Among all the organs, the lung is probably the most difficult to preserve for several reasons: (1) the unique, delicate architecture of the lung poses a special problem in preservation; methods allowing short-term storage of the kidney, liver, and heart have not been successful for lungs; (2) efforts to extend the ischemic period by cooling the lungs with cold gas ventilation, perfusion, or flushing have been ineffective, producing edema in preserved lungs; (3) as with the heart, total functional dependence is required of the preserved lung after it is transplanted, making the functional viability of tissue critical during a preservation period. ${ }^{4}$

Single-flush perfusion of the lungs is currently the most widely practiced technique in lung preservation. However, when simple flushing with various preservation solutions is performed, the results have generally been unsatisfactory, with only a few exceptions. $^{5-7}$ For years, numerous chemicals and modifications, such as prostaglandins, ${ }^{8,9}$ oxygen free-radical scavengers, ${ }^{10,11}$ platelet-activating factor antagonists or leukocyte depletion, ${ }^{12,}{ }^{13}$ corticosteroids, ${ }^{14}$ and other chemicals, ${ }^{15-17}$ have been added to pulmonary flush solutions (e.g., modified EuroCollins solution, University of Wisconsin solution, University of California-Los Angeles solution, Stanford solution, low potassium dextran solution, and Bretschneider's solution). Although various reports have indicated that such chemicals provide improved effects, of which prostaglandins are an excellent example, no additive has shown consistently reliable results. ${ }^{18-22}$ Our results from group 2 animals appear to agree with those of previous reports; that is, when preservation time exceeds 6 hours, lung 


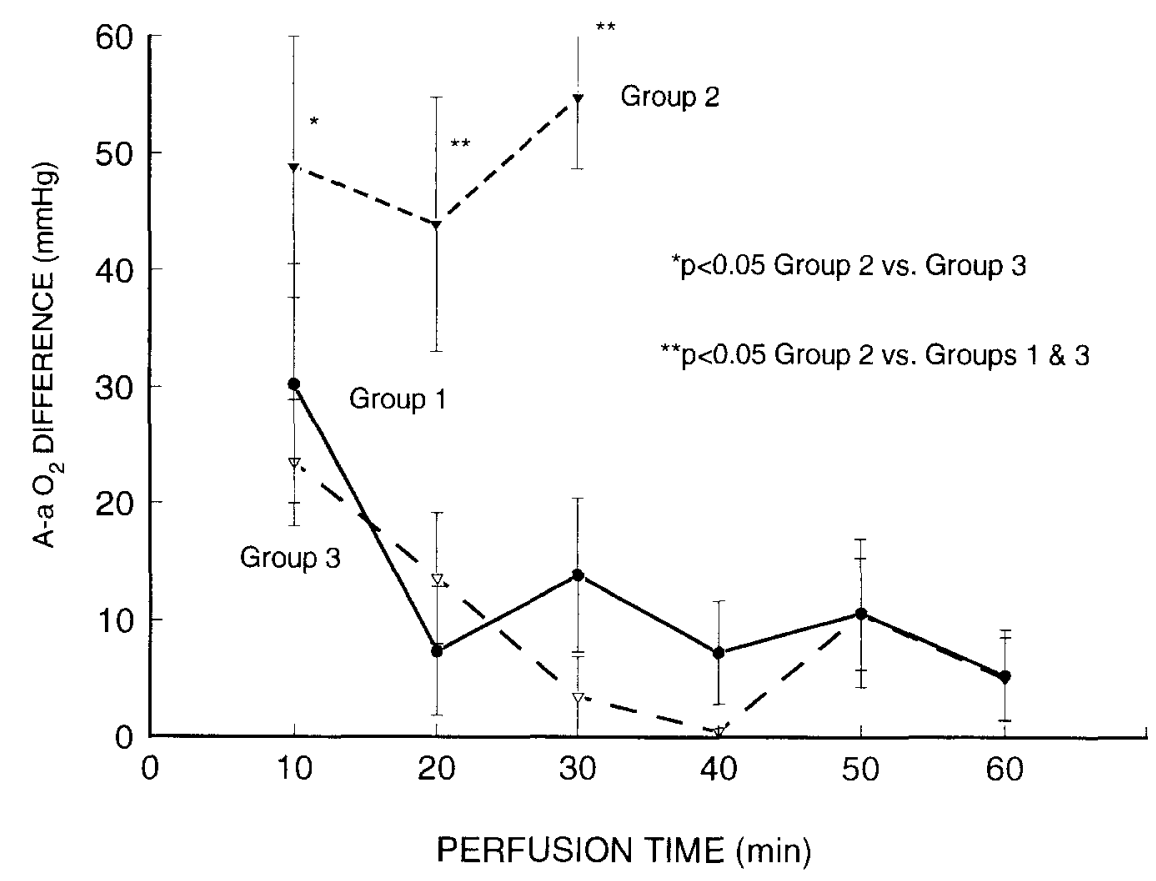

Fig. 5. Comparison of alveolar-arterial oxygen $\left(\mathrm{A}-a \mathrm{O}_{2}\right)$ difference in the three groups.

${ }^{*} \mathrm{p}<0.05$ Group 2 vs. Groups $1 \& 3$

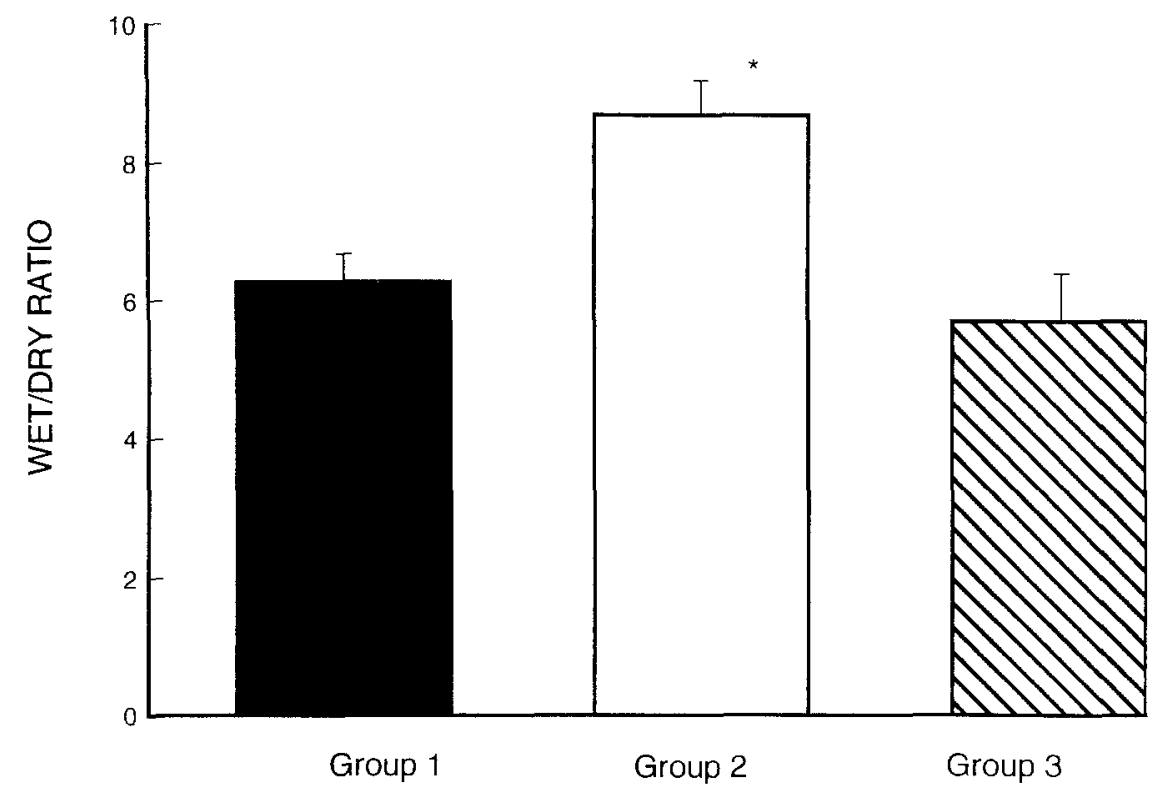

Fig. 6. Lung tissue wet/dry ratios after preservation and perfusion in three groups.

function is severely damaged, as indicated by reduced perfusion flow, increased perfusion pressure, decreased oxygen tension in the pulmonary vein, and increased lung tissue water content. EuroCollins solution alone is known to cause pulmonary vasoconstriction. Although the other aforementioned solutions have been used by many centers in both animal and human models, no solution has been shown to be physiologically successful for safe human lung preservation beyond 6 hours. ${ }^{19,23-26}$ 


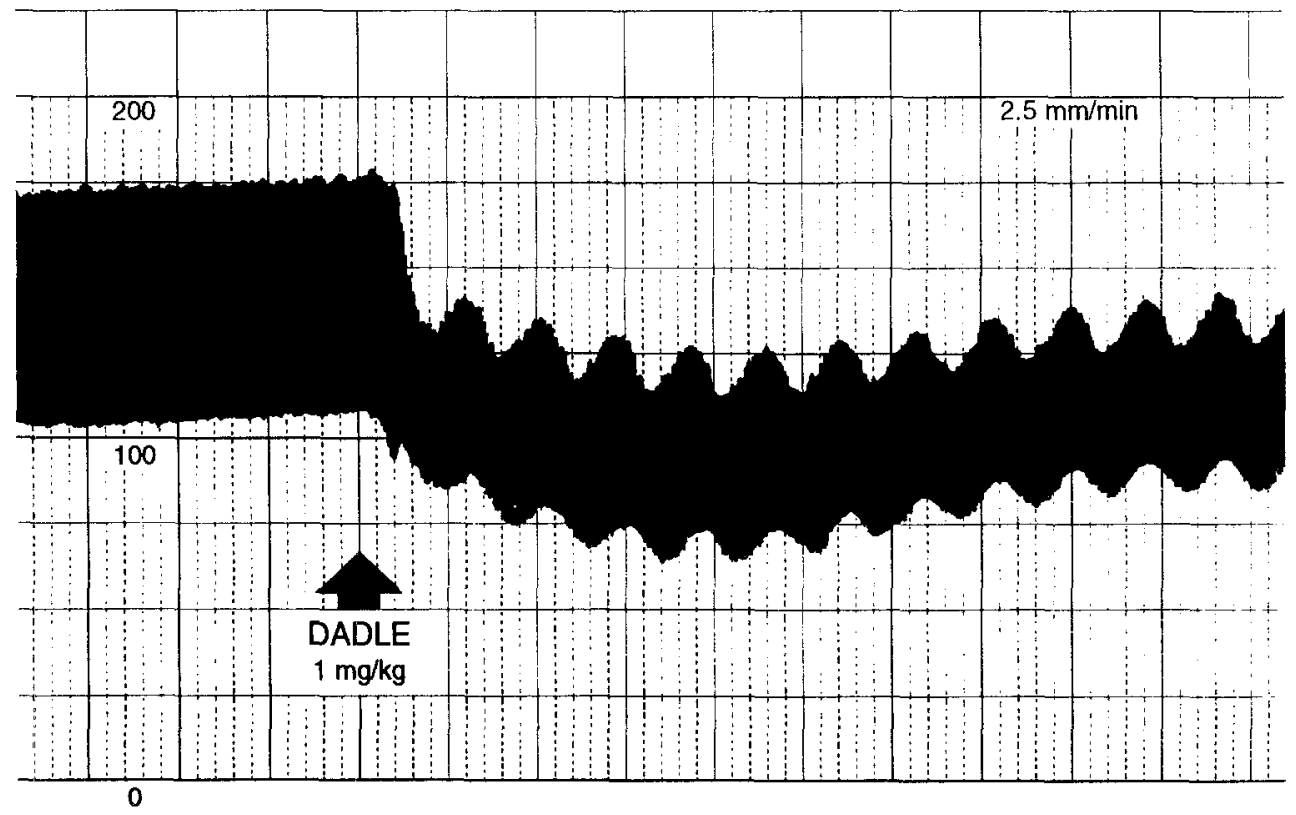

Fig. 7. Effect of DADLE on arterial blood pressure in an anesthetized dog.

Previous studies from our laboratory have shown that DADLE can effectively extend tissue survival time in a normothermic multiorgan preservation block. The mechanism by which DADLE extends tissue survival time in normothermic tissue preservation appears to be its ability to protect tissue from damage during various ischemic insults. The possible mechanisms that might be responsible for tissue protection are as follows: (1) reducing tissue metabolism during ischemia; (2) reducing or eliminating liver congestion; (3) improving tissue perfusion; and (4) reducing platelet/leukocyte aggregation. ${ }^{1,27}$ Of these properties, the elimination of liver congestion and the reduction of platelet/leukocyte aggregation can only be seen during normothermic perfusion. However, if DADLE can reduce tissue metabolism or improve tissue perfusion, it would also protect tissue from ischemic damage during hypothermia. If this is the case, the potential use of this chemical will be tremendous. Not only will it improve organ preservation by adding positive effects to presently used preservation solutions, but it will also enhance the effectiveness of various currently used cardioplegic solutions and possibly that of other hypothermic treatment modalities.

Our results indicate that, when DADLE was added to the Euro-Collins solution, lungs that had been preserved for 24 hours maintained excellent function, a result that has not been achieved in previous reports that used Euro-Collins solution alone. The most noteworthy findings in these studies were the near-normal tissue wet/dry weight ratio along with near normal pulmonary blood flow, pulmonary vascular resistance, and good oxygen-exchanging capacity in the lungs after 24 hours of preservation. In comparison with normal lungs (without preservation), airway resistance in the lungs preserved with DADLE increased only slightly after preservation. The resistance was much lower than that measured in lungs preserved with EuroCollins solution alone.

Because of the complexity of opioids and their receptors, studies to date have primarily concentrated on the reactions of different opioids with different receptors. The effects of opioids on the cardiovascular system have been studied for many years, and the results are controversial. $^{28,29}$ Through a MEDLINE search, we found no reports that related opioid agonists to tissue metabolism or organ preservation other than those that have been published from our laboratory. ${ }^{1,27}$ On the other hand, opioid antagonists, such as naloxone and nalmefene, have been reported to have a tissue protective effect on liver, kidney, and intestine during ischemic insult. This effect is believed to be related to the ability of opioid antagonists to scavenge superoxide..$^{30-32}$

Several possibilities exist for the protective effect 
of opioid agonists such as DADLE on tissue damage from ischemia. The most intriguing of these possibilities relates to a reduction in tissue metabolism. Previous studies have indicated that delta opioid receptors may be responsible for naturally occurring animal hibernation. However, not all the opioid subtypes are involved in hibernation. Infusing morphine, a $\mu$ opioid agonist, into summer-active ground squirrels caused an insignificant bout of hibernation of extremely short duration. Similar results of short bouts of hibernation have been obtained with another peptidic $\mu$ opioid, morphiceptin, a naturally occurring $k$ peptide of brain origin, dynorphin $\mathrm{A}$, and a highly selective synthetic $k$ opioid, U69593. On the other hand, animals receiving implanted pumps containing DADLE began hibernating shortly after implantation and infusion. Continuous subcutaneous administration of naloxone, an opioid antagonist, diminished the frequency and length of hibernation bouts in Citellus tridecemlineatus. ${ }^{33,34}$ These results strongly suggested that the $\mu$ opioid receptor and its ligand are intimately involved in the induction of animal hibernation, and animal hibernation may be induced by a mechanism involving an endogenous opioid that acts through binding to receptor sites. ${ }^{35}$ Thus, it is possible that DADLE protects tissue from various types of damage during ischemia by a mechanism similar to animal hibernation. Inhibition of tissue metabolism or improvement of microcirculation by means of vasodilation probably plays an important role in this protection. We have shown, in previous experiments, a severe reduction of arterial blood pressure after intravenous injection of DADLE into anesthetized animals (Fig. 7). We have not yet performed systemic toxicity tests for DADLE. However, in our multiorgan preservation studies we did not find a toxic effect on any major organ. ${ }^{1}$

Evaluation of lung function after preservation has been hampered by the lack of a reliable testing model. In this study, the viability of the lungs was tested by means of a living rat perfusion model. Venous blood from the host rat perfused the isolated lung. Blood returned from the isolated lung was pumped back into the arterial system of the host. This route reduced the load on the host heart, and the aggregates and particles returned from the isolated lung were filtered by the host's peripheral microvasculature. In this setting, we were able to use one host rat for two to three isolated lung studies totaling five or more hours of perfusion. This model has proved to be simple and stable, yet sensitive for testing isolated lung function. Although it is not always advisable to extrapolate experimental results from tests on small animals to large animals or to human beings, such animal experimentation provides an effective and economical way to screen drugs and solutions for hypothermic lung preservation.

In summary, the present study clearly shows, for the first time, that DADLE has a positive effect on hypothermic preservation of rat lungs. This effect is related to the ability of DADLE to protect tissue from various forms of damage during ischemia. The exact mechanism of this effect is not clear and deserves further study.

We thank Flo Witte for her editorial assistance.

\section{REFERENCES}

1. Chien S, Oeltgen PR, Diana JN, Salley R, Su TP. Extension of tissue survival time in multiorgan block preparation with a delta opioid DADLE ([D-Ala ${ }^{2}$, D-Leu ${ }^{5}$-enkephalin). J Thorac Cardiovasc Surg 1994;107:964-7.

2. Prieto M, Baron P, Andreone PA, et al. Multiple ex vivo organ preservation with warm whole blood. J Heart Transplant 1988;7:227-37.

3. Glick DB, Cronin CS, Jaquiss RDB, Ferguson TB Jr. The extended use of the autoperfusing heart-lung preparation for electrophysiologic studies. Surg Forum 1993;44:309-11.

4. Veith FJ, Montefusco CM. Lung preservation. In: Toledo-Pereyra LH, ed. Basic concepts of organ procurement, perfusion, and preservation for transplantation. 1st ed. New York: Academic Press, 1982: 279-99.

5. Date H, Matsumura A, Manchester JK, et al. Evaluation of lung metabolism during successful twentyfour-hour canine lung preservation. J THORAC CARDiovasC Surg 1993;105:480-91.

6. Kawahara K, Itoyanagi N, Takahashi T, Akamine S, Kobayashi M, Tomota M. Transplantation of canine lung allografts preserved in UW solution for 24 hours. Transplantation 1993;55:15-8.

7. Moriyashu K, McKeown PP, Novitzky D, Snow TR. Preservation of competent rabbit lung function after 30 hours of storage with low-potassium dextran solution. J Heart Lung Transplant 1995;14:75-9.

8. Puskas JD, Cardoso PFG, Mayer E, Shi S, Slutsky AS, Patterson GA. Equivalent eighteen-hour lung preservation with low-potassium dextran or Euro-Collins solution after prostaglandin E-1 infusion. J THORAC CARDIOVASC SuRg 1992;104:83-9.

9. Hirt SW, Wahlers T, Jurmann M, Fieguth HG, Dammenhayn L, Haverich A. Improvement of currently used methods for lung preservation with prostacyclin 
and University of Wisconsin Solution. J Heart Lung Transplant 1992;11:656-64.

10. Aiba M, Yokoyama Y, Snow TR, Novitzky D, McKeown PF. Effects of allopurinol pretreatment with pulmonary flush on lung preservation. J Heart Lung Transplant 1992;11:1025-30.

11. Egan TM, Ulicny KS Jr, Lambert CJ Jr, Wilcox BR. Effect of a free radical scavenger on cadaver lung transplantation. Ann Thorac Surg 1993;55:1453-9.

12. Wahlers $T$, Hirt SW, Haverich $A$, Fieguth $H G$, Jurmann $\mathrm{M}$, Borst HG. Future horizons of lung preservation by application of a platelet-activating factor antagonist compared with current clinical standards. J THORAC Cardiovasc Surg 1992;103:200-5.

13. Schueler S, De Valeria PA, Hatanaka M, et al. Successful twenty-four-hour lung preservation with donor core cooling and leukocyte depletion in an orthotopic double lung transplantation model. J THORAC CaRdiovasc Surg 1992;104:73-82.

14. Novick RJ, Lee J, Sandler D, Menkis AH, McKenzie FN. Marginal benefit of donor corticosteroid therapy in prolonged lung allograft preservation. Transplantation 1992;54:550-3.

15. Hirata T, Yokomise H, Fukuse T, et al. Successful 12-hour lung preservation with trehalose. Transplant Proc 1993;25:1597-8.

16. Hooper TL, Jones MT, Thomson DS, et al. Hypertonic citrate solution as an alternative to modified Euro-Collins' solution for lung preservation. Transplantation 1991;51:1043-8.

17. Keshavjee SH, Yamazaki F, Yokomise H, et al. The role of dextran 40 and potassium in extended hypothermic lung preservation for transplantation. J THORAC Cardiovasc Surg 1992;103:314-25.

18. Locke TJ, Hooper TL, Flecknell PA, McGregor CG. Preservation of the lung: comparison of flush perfusion with cold modified blood and core cooling by cardiopulmonary bypass. J Heart Lung Transplant 1991;10:1-8.

19. Novick RJ, Menkis AH, McKenzie FN. New trends in lung preservation: a collective review. J Heart Lung Transplant 1992;11:377-92.

20. Cooper JD, Vreim CE. NHLBI workshop summary: biology of lung preservation for transplantation. Am Rev Respir Dis 1992;146:803-7.

21. Fullerton DA, Mitchell MB, McIntyre RC Jr, et al. Cold ischemia and reperfusion each produce pulmonary vasomotor dysfunction in the transplanted lung. J Thorac Cardiovasc Surg 1993;106:1213-7.

22. Kirk AJB, Colquhoun IW, Dark JH. Lung preservation: a review of current practice and future directions. Ann Thorac Surg 1993;56:990-1000.

23. Semik M, Moller F, Lange V, Bernhard A, Toomes H. Comparison of Euro-Collins and UW-1 solutions for lung preservation using the parabiotic rat perfusion model. Transplant Proc 1990;22:2235-6.

24. Xiong L, Mazmanian M, Chapelier AR, et al. Lung preservation with Euro-Collins, University of Wisconsin, Wallwork, and low-potassium-dextran solutions. Ann Thorac Surg 1994;58:845-50.

25. Fehrenbach H, Hirt SW, Wahlers T, Schnabel PA, Haverich A, Richter J. Euro-Collins flush perfusion in human lung preservation-ultrastructural studies of the preservation quality of the contralateral donor lung in clinical single lung transplantation. J Heart Lung Transplant 1994;13:1-14.

26. Toledo-Pereyra LH, Rodriguez FJ. Scientific basis and current status of organ preservation. Transplant Proc 1994;26:309-11.

27. Chien S. Extending organ survival time using delta opioid (DADLE). In: Chien S, Oeltgen PR, eds. Hibernation induction trigger for organ preservation. Austin: R.G. Landes, 1993:88-105.

28. Feuerstein G. The opioid system and central cardiovascular control: analysis of controversies. Peptides 1985;6(Suppl 2):51-6.

29. Szeto HH, Zhu YS, Cai LQ. Central opioid modulation of fetal cardiovascular function: role of $\mu$ - and ס-receptors. Am J Physiol 1990;258:R1453-8.

30. Naujokat P, Xavier R, Lopez J, Walters W, ToledoPereyra LH. Role of opioid antagonists in the rat liver ischemia model. Transplant Proc 1991;23: 2426-7.

31. Toledo-Pereyra LH, Frantzis P, Prough D, et al. Better renal function with naloxone treatment following hemorrhage and brain death. Transplant Proc 1990;22:462-3.

32. Vega RG, Toledo-Pereyra LH. Acute mesenteric small bowel ischemia in the rat. I. Protective effect of naloxone. Transplantation 1990;49:830-3.

33. Spurrier WA, Oeltgen PR, Myers RD. Hibernation "trigger" from hibernating woodchucks (marmota monax) incudes physiological alterations and opiatelike responses in the primate (macacca mulatta). J Therm Biol 1987;12:139-42.

34. Oeltgen PR, Welborn JR, Nuchols PA, Spurrier WA, Bruce DS, Su TP. Opioids and hibernation. II. Effects of kappa opioid U69593 on induction of hibernation in summer-active ground squirrels by "hibernation induction trigger" (HIT). Life Sci 1987;41:2115-20.

35. Bruce DS, Cope GW, Elam TR, Ruit KA, Oeltgen PR, Su TP. Opioids and hibernation. I. Effects of naloxone on bear HIT's depression of guinea pig ileum contractility and on induction of summer hibernation in the ground squirrel. Life Sci 1987; 41:2107-13. 